\title{
STRUCTURAL ELUCIDATION OF BIOACTIVE SECONDARY METABOLITES FROM ENDOPHYTIC FUNGUS
}

\author{
SHIV KR VERMA, MOTI LAL, MIRA DEBNATH (DAS)* \\ School of Biochemical Engineering IIT, Banaras Hindu University, Varanasi, Uttar Pradesh, India. \\ Email: m.debnath.bce@itbhu.ac.in
}

Received: 04 April 2017, Revised and Accepted: 04 May 2017

\section{ABSTRACT}

Objective: In this research for bioactive secondary metabolites from endophytic fungal isolate CPR5, which was later identified and characterized as Aspergillus niger sp.

Methods: Eight bioactive compounds (1-8) were isolated and purified using a series of chromatographic techniques and identified by applying ${ }^{13} \mathrm{C}$ and ${ }^{1} \mathrm{H}$ nuclear magnetic resonance and mass (ESI-MS spectrometry).

Results: All the compounds were tested for antimicrobial activity against a wide range of human and plant pathogenic bacteria as well as fungi. These microorganisms were, Xanthomonas oryzae, Escherichia coli, Streptococcus pneumonia, Bacillus subtilis, Staphylococcus hyicus, Bacillus sphaericus, Staphylococcus aureus, and Pseudomonas aeruginosa, Candida albicans, Sclerotium rolfsii, Sclerotinia, scleratiourum, and Phoma exigua minimum inhibitory concentration value have also been determine for these microorganism.

Conclusion: In this study, a total 10 endophytic fungi were isolated from the Calotropis procera, show a great antibacterial activity against 24 human pathogenic bacteria.

Keywords: Endophytic fungi, Antimicrobial metabolites, Calotropis procera, Preliminary analysis of bioactive compounds and characterization.

(C) 2017 The Authors. Published by Innovare Academic Sciences Pvt Ltd. This is an open access article under the CC BY license (http://creativecommons. org/licenses/by/4. 0/) DOI: http://dx.doi.org/10.22159/ajpcr.2017.v10i7.18909

\section{INTRODUCTION}

Endophytes are the group of microorganisms that reside inside plant tissues without causing any negative sign on the host [1]. This is a topographical term and includes bacteria, fungi, Actinomycete, and Algae, which spend their whole life or a period of the life cycle in the symplast or apoplast region of healthy plant tissues without producing any disease or clinical symptoms. Studies have revealed that fungal endophytes are almost everywhere in many plant species that live on the earth, and the endophytic colonization differs from plant to plant [2]. These fungi mostly belong to the phyla Ascomycetes, Basidiomycetes, and Zygomycota [3]. Endophytes in general, are very important and viable components of microbial biodiversity. They have also been reported in mangrove community [4]. Ecological success and protection of plants are greatly affected by symbiotic microorganisms which once isolated and characterized, may also have potential for use in industry, agriculture, and medicine [4-6]. Endophytic fungi have been widely investigated as source of variety of new bioactive compounds [7]. Plantassociated microbial diversity often shows a symbiotic relationship. The endophytes may provide protection and survival conditions to their host plant by producing a plethora of substances to nullify the effects of soil toxic compounds, fungal and bacterial infection and from attack of herbivores or by enhancing plant responses [8]. There may be possibility that the medicinal characteristics of plants may result from the potential of its endophytes to generate biologically active secondary metabolites. In recent years, the biology of endophytic fungi in aerial plant tissues has become an important area for study; however, the chemistry of bioactive metabolites isolated from these organisms is main interesting area to be explored along with other biological aspects [9]. There is numerous evidence showing that bioactive substances produced by microbial endophytes may not only involve in the host-endophyte relationship, but may also have diverse applicability in medicine, agriculture, and industry. Recent reported literatures has explored that endophytic fungi have been identified as unusual productive sources of bioactive metabolites [10,11], which might be helpful to treat some of the recently observed diseases in a human being. Due to the increasing demand of medicine and destruction of medicinal plants, a huge work carried out in the field of endophytes for producing bioactive compounds that can be used in the treatment of diseases [12] Endophytic fungi have been widely investigated as source of variety of bioactive compounds. Bioactive compounds show interesting and attractive properties such as antibacterial, antifungal, anticancer, antiprotozoal, antioxidant, antiviral, antimalarial, antitubercular, immunosuppressive, antidiabetic, and antiviral. These bioactive compounds could be mainly classified as alkaloids, steroids, terpenoids, quinones, phenylpropanoids, isocoumarins, lignans, phenols, lactones, etc. These bioactive compounds used for the health care purpose for human beings [13]. Even though more than 30,000 diseases are clinically described today, less than onethird of these can be treated symptomatically, and even a fewer can be cured. The increasing occurrence of multiresistant pathogenic strains has limited the effect of traditional antimicrobial treatment. Hence, there is an urgent need for new therapeutic agents with infectious disease control [14]. The main aim of the study was to screen and isolate endophytic fungus from the latex bearing medicinal plant (Calotropis procera), extraction of bioactive secondary metabolite from it using ethyl acetate solvent. During our continual search for bioactive secondary metabolites from microorganisms, extracts (supernatant and cells) of the endophytic fungal strain Aspergillus niger sp. CPR5 showed strong antibacterial and antifungal activities. Minimum inhibitory concentration (MIC) was also determined. In addition, eight compounds have been isolated, and their structure was elucidated using nuclear magnetic resonance (NMR) and mass spectroscopy.

\section{METHODS}

\section{Plant sample collection}

Root samples of $C$. procera were collected from agricultural field of Banaras Hindu University (BHU), Varanasi (25.5-N 82.9-E, elevation 
$279 \mathrm{ft} / 85 \mathrm{~m})$. The plant was identified on the basis of external morphology and visualization features. A complete mature and healthy plant was rooted out from soil surface. The samples were collected in sterile polythene bags and brought to the laboratory in an ice container. Samples were preserved at $4^{\circ} \mathrm{C}$ and processed for isolation of desired fungus immediately.

\section{Isolation and extraction of endophytic fungus}

Before applying any chemical treatment, roots were washed in running tap water for 10-12 minutes, to remove heavy load of soil particle and microbial concentration followed by washing with double distilled water. Samples were successively surface sterilized by the method given by [15]. Sample fragments were successively surface sterilized by immersing in $70 \%(\mathrm{v} / \mathrm{v})$ ethanol for 1-3 minutes followed by washing with $5 \%$ aqueous solution of sodium hypochlorite for 5 minutes and again in $70 \%$ ethanol for 30 seconds. After being rinsed in sterile water for 3 times, the roots were cut into 1 -cm-length bars. The bars were longitudinally halved and incubated in Petri dishes containing potato dextrose agar (PDA) medium supplemented with chloramphenicol $(50 \mu \mathrm{g} / \mathrm{ml}$,) and streptomycin sulfate $(250 \mu \mathrm{g} / \mathrm{ml})$ to suppress bacterial growth PDA medium at $28^{\circ} \mathrm{C}$ until the mycelia or colonies appeared around the segments.

\section{Identification and molecular characterization of the fungus}

Morphologically fungus was studied using lactophenol cotton blue staining; isolate was identified at genus level based on mycelial morphology and for identification and characterization at molecular level, total DNA of the endophytic fungus isolate was extracted from fungal mycelia grown in PDA using PrepMAN ultra sample preparation reagent kit according to the manufacture's recommendation (nucleopore). For identification and identification internal transcribed spacer region. A pair of ITS primer IT1 (5'GTAGTCATATGCTTGTCTC 3') [Qiagen] and IT4 (5' CTTCCGTCAATTCCTTTAAG 3') [Qiagen] were used to amplify the highly specific and conserved sequence for endophytic fungi. Polymerase chain reaction (PCR) was carried out in a programmable thermal controller (Bio-rad) (Verma et al., 2016) In PCR reaction mixture of a total volume of $2.5 \mu \mathrm{l}$, it contained $10 \mu \mathrm{l}$ template DNA, $14.5 \mu \mathrm{l}$ PCR master mix (PCR buffer, $4 \mathrm{mM} \mathrm{MgCl}_{2}, 0.4 \mathrm{mM}$ of each $\mathrm{dNTP}$, and $0.05 \mathrm{U} / \mu \mathrm{l}$ Taq polymerase) [Fermentas], $1 \mu \mathrm{l}$ of each primer (IS1 and IS4) and double distilled water to make up the volume. The amplification was performed for 34 cycles having preset program of 1 minute at $94^{\circ} \mathrm{C}, 1$ minute at $45^{\circ} \mathrm{C}$, and 2 minutes at $72^{\circ} \mathrm{C}$. After the final cycle has been completed, the amplification was extended for 10 minutes at $72^{\circ} \mathrm{C}$. The amplified DNA fragment (approximately $400 \mathrm{bp}$ ) was purified and was sequenced by genetic analyzer. The sequences were compared to rDNA-ITS gene sequences in the public database using the BlastN program (http://www.ncbi.nlm.nih.gov). The phylogenetic tree was produced using BLAST pairwise alignments.

\section{Microorganisms tested and antimicrobial activity test}

Escherichia coli, Bacillus subtilis, Staphylococcus aureus, Pseudomonas aeruginosa, and human pathogenic fungus, Candida albicans and three plant pathogenic fungi Sclerotium rolfsii, Sclerotinia scleratiourum, and Penicillium sp. were used to test antimicrobial activity fungal extract. Disc diffusion method [16] was followed for all the microorganisms. The microbial suspensions of particular concentration $(O D=0.5)$ were evenly spread out with sterile glass spreader. Sterile paper disks (6 mm diameter) were placed in the center of each Petri plate and loaded with $15 \mu \mathrm{l}$ of crude extract and sealed with parafilm. Bacterial plates were incubated at $36 \pm 2^{\circ} \mathrm{C}$ for $24 \mathrm{hrs}$ and fungal plates at $27^{\circ} \mathrm{C}$ for $48 \mathrm{hrs}$, respectively. The zone of inhibition was recorded after the specified incubation period. Three replicates of each experiment were maintained to avoid error in measurements.

\section{Cultivation and metabolite extraction}

A piece of agar plug $\left(0.3 \times 0.3 \mathrm{~cm}^{2}\right)$ containing fungal hyphae was transferred in each $250 \mathrm{ml}$ Erlenmeyer flask containing $100 \mathrm{ml}$ sterile medium (yeas extract $3.0 \mathrm{~g} / \mathrm{l}$; malt extract $3.0 \mathrm{~g} / \mathrm{l}$; peptone $0 \mathrm{~g} / \mathrm{l}$; glucose $10 \mathrm{~g} / \mathrm{l}$ ), and incubated on a rotary shaker at $140 \mathrm{rpm}$ and at $28 \pm 2{ }^{\circ} \mathrm{C}$ for
8-10 days. A total of 50 flasks were used to collect required volume of broth. Thereafter, a total of $5 \mathrm{l}$ fermentation broth was collected for each isolate (CPR1-CPR18). The filtrate was extracted 3 times with an equal volume of ethyl acetate (EtOAc) and the EtOAc layer was collected. The frozen mycelia was crushed completely and extracted 3 times repeatedly by ultrasonic treatment and with EtOAc. Both the broth extract mycelial extract were combined and evaporated in a rotatory vacuum dryer till solid residue remained. Crude extract was evaporated to make solid residue and the stock solution was prepared in the concentration of $1 \mathrm{mg} / \mathrm{ml}$ in dimethyl sulfoxide (DMSO).

\section{Antimicrobial activity of fungal extracts}

Antimicrobial activity of fungal crude extracts was examined using paper disc diffusion method. $15 \mu \mathrm{l}$ of crude extract from stock solution (1 $\mathrm{mg} / \mathrm{ml})$ was added into sterile filter paper disc (6 mm diameter). Discs with the crude extract were placed over Petri plates inoculated with test organisms. All the plates were incubated at $37^{\circ} \mathrm{C}$ for $24 \mathrm{hrs}$. The zone of inhibition was measured and expressed in $\mathrm{mm}$.

\section{Spectroscopic measurements}

To predict the chemical structure of nine antimicrobial compounds isolated, they were analyzed using Fourier Transform Infrared (FT-IR), NMR spectroscopy. All NMR data were collected on JEOL AL 300 FTNMR. Mass spectra were recorded (ESI-HRMS) mass spectrometer. Chemical shift was expressed in $\delta$ (ppm) and coupling constant $\mathrm{J}$ in $\mathrm{Hz} .{ }^{1} \mathrm{H}$ and ${ }^{13} \mathrm{C}$ NMR spectra were recorded on JEOL AL 300 FTNMR spectrometer. Mass spectra were recorded on Agilent 6520 Q-TOF (ESI-HRMS) mass spectrometer. Solvents were distilled before use, and spectral grade solvents were used for spectroscopic measurements.

\section{Fractionation of crude extract}

Concentrated and dried crude extract (12 g), which was subjected to column chromatography over silica gel column (150 g) and eluted with n-hexane and ethyl acetate gradient $(100: 0,90: 10,800: 20,70: 30,60: 40$, $50: 50,40: 60,30: 70,20: 80,10: 90,0: 100$, and v/v). Still the column had retained the mixture of compounds. Thereafter, the column was eluted with chloroform and methanol (4:1, 3:2 1:1, and $\mathrm{v} / \mathrm{v})$ finally the column was eluted to methanol and acetone $(4: 1,3: 21: 1$, and $v / v)$. Based on the thin-layer chromatography (TLC) monitoring, the collected fractions (50 ml each) were combined into eight parts; (F-1: $3.5 \mathrm{~g}, \mathrm{~F}-2,1.20 \mathrm{~g}$; F-3, 0.80 g; F-4:1.0 g; F-5:2.5 g; F-6:75 g, F-7:0.550 g; F-8:1.10 g). The separation column $(125 \times 40 \mathrm{~mm})$ was prefilled with Eurospher-10 C18 (Knauer, Germany) using a linear gradient of $\mathrm{MeOH}$ and $0.02 \%$ $\mathrm{H}_{3} \mathrm{PO}_{4}$ in $\mathrm{H}_{2} \mathrm{O}$ and a flow rate of $1 \mathrm{ml} /$ minute. Ultraviolet (UV) data (k max) for individual compounds were extracted from the online UV spectra provided by the instrument software. TLC plates with silica gel F254 (Merck, Darmstadt, Germany) were used for monitoring of fractions using n-hexane: EtOAc (95:5 and 90:10), $\mathrm{CH}_{2} \mathrm{Cl}_{2}: \mathrm{MeOH}$ (95:5, 90:10, 85:15, and 80:20) as well as $\mathrm{CH}_{2} \mathrm{Cl}_{2}: \mathrm{MeOH}: \operatorname{EtOAc}(90: 10: 5$ and $80: 20: 10$ ). Detection was at 254 and $366 \mathrm{~nm}$ or by spraying the plates with anisaldehyde reagent.

\section{RESULTS AND DISCUSSION}

\section{Morphological and molecular identification of Fungal isolate}

About 18 endophytic fungal isolate have been isolated form C. procera plant and tested for antimicrobial activity and among the 18 isolate, only one strain, which produced the wide-spectrum antibacterial substances with the highest efficiency, was selected for morphological and molecular identification. The growth of mycelia colonies found to be opaque and almost circular when grown on PDA at $34^{\circ} \mathrm{C}$ for 4 days. Representative image of endophytic fungal mycelia (40X inverted microscope) was obtained in the laboratory as image taken from 1 week old liquid culture it clearly shown that dense mycelia are intermingled with each other (Fig. 1). The 18S rRNA sequencing (Fig. 2) followed by basic local alignment search tool (BLAST) and SeqMatch analysis was used for molecular conformation endophytic isolate. The $18 \mathrm{~S}$ rRNA sequence was submitted to the DNA Data Bank of Japan and assigned an accession number (LC062385). The 18S rRNA gene sequence (Fig. 2) 
was used to build a phylogenetic tree (Fig. 3), by performing automated BLASTN searches, to determine the closest type strain to the isolate under investigation. The percentage of identity was found to be $96 \%$. Phylogenetic tree analysis indicated that $18 \mathrm{~S}$ ribosome RNA sequence of CPR-5 strain was closely related to A. niger species (Fig. 2). The phylogenetic tree suggested that the local isolated strain is definitely a member of the genus Aspergillus and formed a common phylogenetic lineage that could be equated with a novel local species. From the results of inhibition zone it is observed that the metabolite is abroad spectrum antimicrobial agent, it inhibits growth of both Gram-positive and Gram-negative bacteria. $1 \mathrm{mg} / \mathrm{ml}$ of crude metabolite was used in the experiment. Maximum zone of inhibition was recorded. Against Klebsiella pneumonia $(21 \mathrm{~mm})$ followed by E. coli $(20 \mathrm{~mm})$. Equal zone of inhibition (18 mm) was observed for Vibrio sp. and Bacillus sp. The inhibition zones against Pseudomonas sp., Salmonella typhi 16.02, 17.02. Similarly, when antifungal activity was tested it was observe that equal zone of inhibition $(18 \mathrm{~mm})$ was observed for Penicillium chrysogenum and S. rolfsii. Minimum zone of inhibition (16 $\mathrm{mm})$ was recorded for Candida tropicalis. Zone of inhibition of 18 and $17 \mathrm{~mm}$ was observed for S. scleratiourum and Phoma exigua. Maximum zone of inhibition was recorded for K. pneumonia (Table 1). These observations were obtained from crude metabolites and the results compared with fluconazole as a standard. From Table 2 it is clear that the metabolite from this isolate could be a promising source of antifungal agents. The antibacterial activity of bioactive compound produced by isolates CPR5 is comparable with chloramphenicol as standard antibiotic (Table 1).

\section{Spectroscopic analysis of compounds}

\section{Compound 1}

Dark brown solid like compound, composition (64.25\%) H (10.39\%) 0 (25.36\%) molecular formula $\mathrm{C}_{27} \mathrm{H}_{52} \mathrm{O}_{8}$, ESI-MS (m/z) 504.69698.

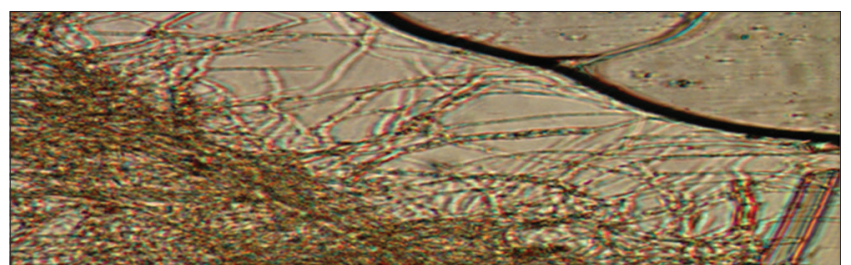

Fig. 1: Representative image of endophytic fungal mycelia $(\times 40$ inverted microscope)
${ }^{1} \mathrm{H} \quad$ NMR $\quad$ (DMSO-d, 300 MHZ) 1.25-145 ppm (m, 20H), $3.21(\mathrm{~m}, 2 \mathrm{H}), 3.90(\mathrm{~m}, 1 \mathrm{H}), 0.90(\mathrm{~d}, 6 \mathrm{H}), 1.18(\mathrm{~d}, 3 \mathrm{H}), 1.79(\mathrm{~m}, 1 \mathrm{H})$, 4.40-1.80 (m, H-pentose), 3.58 (m, 3H), ${ }^{13} \mathrm{C}$ NMR (75 MHZ) DMSO-d; 172-174 ppm $(-\mathrm{C}=0), 163 \mathrm{ppm}$ (amid group), $110 \mathrm{ppm}(\mathrm{C}=\mathrm{C}), 27-$ $38 \mathrm{ppm}$ (C-C), $73 \mathrm{ppm}$ (C-OH), 85-93 ppm (C-O-C) IR (KBr) vmax $\left(\mathrm{cm}^{-1}\right)$ 3250, 1200 (Fig. 3).

Compound 1 was observed active against:

E. coli, Streptococcus pneumonia, B. subtilis, Staphylococcus hyicus, Bacillus sphaericus, S. aureus, and pseudomonas aeruginosa, C. albicans, S. rolfsii, Sclerotinia, scleratiourum, Fusarium species, and Penicillin sp.

\section{Compound 2}

Black brown solid like, composition: C (62.65\%) H (9.62\%) N (5.35\%) $\mathrm{O}(22.39 \%)$ molecular formula $\mathrm{C}_{41} \mathrm{H}_{75} \mathrm{~N}_{3} \mathrm{O}_{11}$, ESI-MS (m/z) 785.539612.

${ }^{1} \mathrm{H}$ NMR (DMSO- $\mathrm{d}_{6}, 300 \mathrm{MHZ}$ ), 3.3-3.8 ppm (m, 2H-glucose), 4.43 (m,2H), $4.52(\mathrm{~m}, 1 \mathrm{H}), 7.10-7.90\left(\mathrm{~m}, 4 \mathrm{H}-\mathrm{NH}_{2}\right), 1.96(\mathrm{t}, 4 \mathrm{H}), 1.33(\mathrm{t}, 2 \mathrm{H}), 1.29$ (m, 10H), $1.25(\mathrm{~m}, 12 \mathrm{H}), 5.62-5.7(\mathrm{~m}, 4 \mathrm{H}), 4.85(\mathrm{~s}, 1 \mathrm{H}), 0.96(\mathrm{~d}, 3 \mathrm{H}),{ }^{13} \mathrm{C}$ NMR (75 MHZ) DMSO; 172-174 ppm ( $-\mathrm{C}=0), 163 \mathrm{ppm}$ (amide group), $110 \mathrm{ppm}(\mathrm{C}=\mathrm{C}), 27-38 \mathrm{ppm}(\mathrm{C}-\mathrm{C}), 73 \mathrm{ppm}(\mathrm{C}-\mathrm{OH}), 75 \mathrm{ppm}(\mathrm{C}-\mathrm{O}-\mathrm{C})$. IR $(\mathrm{KBr}) v \max \left(\mathrm{cm}^{-1}\right) 3250,1200,1650,1000$, and 1062.

The results are near about similar to [17] (Fig. 4).

Compound 2 was observed active against:

Xanthomonas oryzae, E. coli, S. pneumonia, B. subtilis, Staphylococcus hyicus, B. sphaericus, S. aureus, and P. aeruginosa, C. albicans, S. rolfsii, P. exigua, and S. scleratiourum.

\section{Compound 3}

Dark brown solid like, composition: C (67.98\%) H (10.73\%) N (1.89\%) $\mathrm{O}(19.40 \%)$ molecular formula $\mathrm{C}_{42} \mathrm{H}_{79} \mathrm{NO}_{9}$, ESI-MS (m/z) 742.07796.

${ }^{1} \mathrm{H}$ NMR (DMSO-d, $300 \mathrm{MHZ}$ ), 3.3-3.8 ppm (m, 2H-glucose), $4.43 \mathrm{ppm}$ $(\mathrm{m}, 2 \mathrm{H}), 4.52 \mathrm{ppm}(\mathrm{m}, 1 \mathrm{H}), 1.96(\mathrm{t}, 4 \mathrm{H}), 1.33(\mathrm{t}, 2 \mathrm{H}), 1.29(\mathrm{~m}, 10 \mathrm{H})$, $1.25(\mathrm{~m}, 12 \mathrm{H}), 5.62-5.7(\mathrm{~m}, 4 \mathrm{H}), 4.85(\mathrm{~s}, 1 \mathrm{H}), 0.96(\mathrm{~d}, 3 \mathrm{H}), 0.88(\mathrm{~m}$,

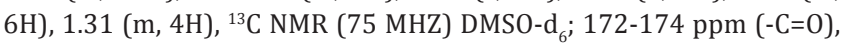
$163 \mathrm{ppm}$ (amid group), $110 \mathrm{ppm}(\mathrm{C}=\mathrm{C}), 27-38 \mathrm{ppm}(\mathrm{C}-\mathrm{C}), 73 \mathrm{ppm}$ (C-OH), 75 ppm (C-O-C), 134-135 ppm (C=C). IR (KBr) vmax cm${ }^{-1} 3400$, $1650,3100,1000$, and 1062 . The results are near about similar to (Fig. 5) [17].

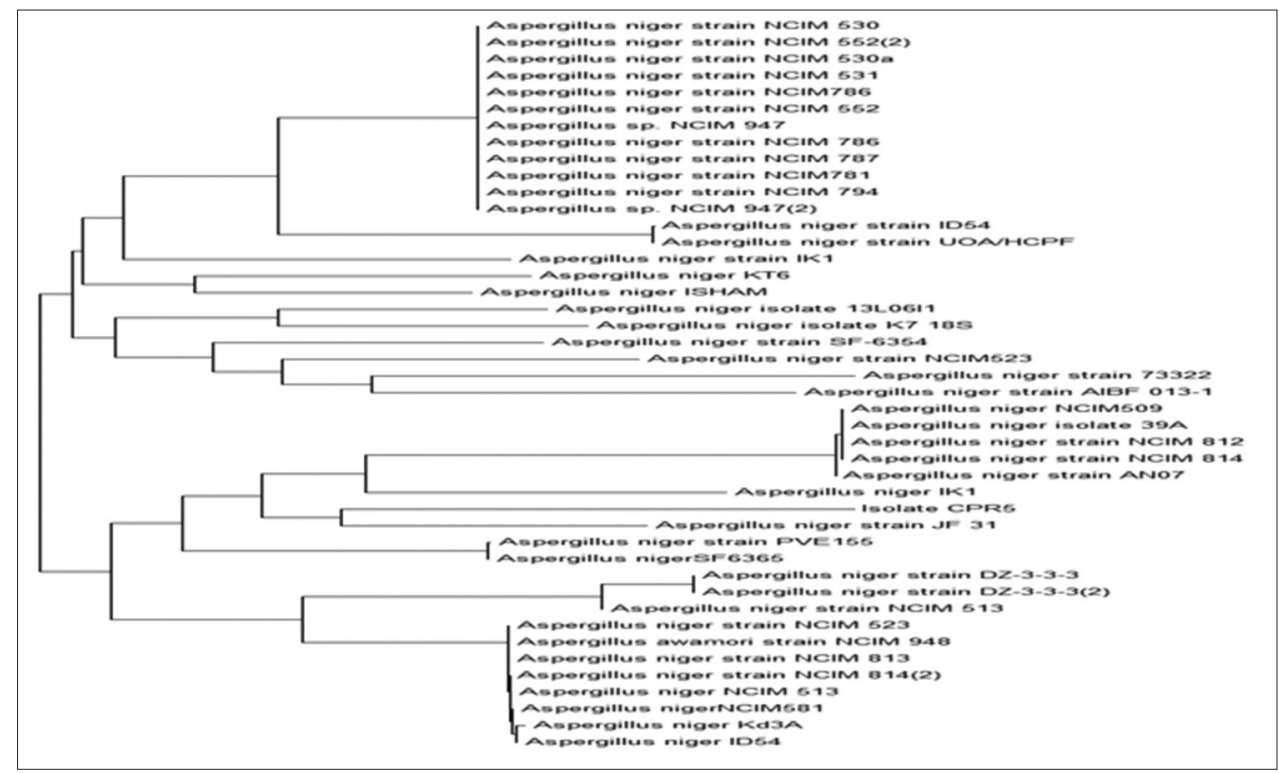

Fig. 2: Phylogenic tree based on $18 \mathrm{~S}$ rRNA sequence showing the relationship between fungal endophytic isolate from Calotropis procera (isolate CPR5) and reference strains, the evolutionary history was inferred using UPGMA method 
Table 1: Antifungal activity (inhibition zone) of the crude aqueous extracts of isolate CPR5

\begin{tabular}{|c|c|c|c|c|c|}
\hline \multirow[t]{2}{*}{ Plant pathogenic fungi } & \multicolumn{2}{|c|}{ Zone of inhibition (mm) } & \multirow{2}{*}{$\begin{array}{l}\text { Plant pathogenic } \\
\text { bacteria }\end{array}$} & \multicolumn{2}{|c|}{ Zone of inhibition (mm) } \\
\hline & $\begin{array}{l}\text { Crud } \\
\text { extract }\end{array}$ & Fluconazole (+ve control) & & $\begin{array}{l}\text { Crud } \\
\text { extract }\end{array}$ & Chloramphenicol (+ve control) \\
\hline Penicillium chrysogenum & $3.35 \pm 0.2$ & $10.5 \pm 0.2$ & Ralstonia solanacearum & $7.15 \pm 0.2$ & $18.4 \pm 0.2$ \\
\hline Phoma exigua & $2.21 \pm 0.2$ & $12.4 \pm 0.2$ & Xanthomonas oryzae & $6.85 \pm 0.2$ & $13.3 \pm 0.2$ \\
\hline Sclerotium rolfsii & $4.38 \pm 0.2$ & $10 \pm 0.2$ & Xanthomonas campestris & $8.38 \pm 0.2$ & $16.3 \pm 0.2$ \\
\hline Sclerotinia scleratiourum & $5.15 \pm 0.2$ & $11.3 \pm 0.2$ & Pseudomonas spp. & $6.0 \pm 0.2$ & $16.3 \pm 0.2$ \\
\hline Fusarium oxysporum & $4.54 \pm 0.2$ & $12.7 \pm 0.2$ & Human pathogenic fungus & & \\
\hline Rhizoctonia spp. & $5.84 \pm 0.2$ & $9.5 \pm 0.2$ & Candida albicans & $4.54 \pm 0.2$ & $10.5 \pm 0.2$ \\
\hline Fusarium verticillioides & $3.45 \pm 0.2$ & $14.5 \pm 0.2$ & & & \\
\hline Penicillium expansum & $2.21 \pm 0.2$ & $8.9 \pm 0.2$ & & & \\
\hline
\end{tabular}

Table 2: Antibacterial activity (inhibition zone) of the crude aqueous extracts of isolate CPR5 against human pathogenic bacteria

\begin{tabular}{|c|c|c|c|}
\hline \multirow[t]{2}{*}{ Test bacteria } & \multirow{2}{*}{$\begin{array}{l}\begin{array}{l}\text { Zone of } \\
\text { inhibition }(\mathrm{mm})\end{array} \\
\text { Crud extract }(\mathrm{mg} / \mathrm{ml})\end{array}$} & \multicolumn{2}{|l|}{ MIC } \\
\hline & & Crud extract $(\mu \mathrm{g} / \mathrm{ml})$ & Chloramphenicol (+ve control) $(\mu \mathrm{g} / \mathrm{ml})$ \\
\hline Escherichia coli 0157:H7 & $22.0 \pm 0.2$ & 130 & 50 \\
\hline Bacillus cereus & $24.75 \pm 0.2$ & 230 & 40 \\
\hline Bacillus subtilis & $22.25 \pm 0.2$ & 230 & 45 \\
\hline Staphylococcus aureus & $19.0 \pm 0.2$ & 330 & 50 \\
\hline Bacillus megaterium & $16.0 \pm 0.2$ & 200 & 35 \\
\hline Helicobacter pylori & $15.12 \pm 0.2$ & 270 & 70 \\
\hline Streptococcus pyogenes & $14 \pm 0.2$ & 310 & 100 \\
\hline M. D. R Staphylococcus aureus & $18.0 \pm 0.2$ & 280 & 80 \\
\hline Chlamydia pneumonia & $17.15 \pm 0.2$ & 220 & 70 \\
\hline Corynebacterium amycolatum & $14.0 \pm 0.2$ & 270 & 110 \\
\hline Mycobacterium tuberculosis & $11.5 \pm 0.2$ & 270 & 150 \\
\hline Staphylococcus epidermis & $25.5 \pm 0.2$ & 322 & 45 \\
\hline Pseudomonas aeruginosa & $24.35 \pm 0.2$ & 330 & 30 \\
\hline Listeria monocytogenes & $16.5 \pm 0.2$ & 300 & 75 \\
\hline Salmonella typhimurium & $15.20 \pm 0.2$ & 300 & 130 \\
\hline Salmonella typhi & $11.19 \pm 0.2$ & 330 & 150 \\
\hline Streptococcus pneumoniae & $16.85 \pm 0.2$ & 280 & 75 \\
\hline Staphylococcus epidermidis & $15.85 \pm 0.2$ & 300 & 120 \\
\hline Corynebacterium diphtheriae & $17.0 \pm 0.2$ & 220 & 80 \\
\hline Vibrio sp. & $11.85 \pm 0.2$ & 350 & 40 \\
\hline Clostridium difficile & $14.55 \pm 0.2$ & 300 & 120 \\
\hline Klebsiella pneumonia & $28.38 \pm 0.2$ & 220 & 45 \\
\hline Enterococcus faecalis & $19.45 \pm 0.2$ & 31 & 55 \\
\hline Enterococcus faecium & $18.05 \pm 0.2$ & 32 & 85 \\
\hline
\end{tabular}

MIC: Minimum inhibitory concentration

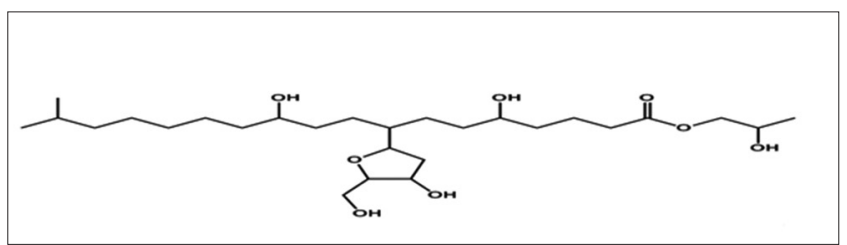

Fig. 3: 3-hydroxypropyl 5, 11-dihydroxy-8-(4-hydroxy-5-(hydroxyl methyl) tetrahydrofuran-2-yl) 17-methyleoctadecanate

Compound 3 was observed active against:

E. coli, S. pneumonia, B. subtilis, B. sphaericus, S. aureus, and pseudomonas aeruginosa, C. albicans, S. rolfsii, P. exigua, Sclerotinia, and S. scleratiourum.

\section{Compound 4}

Dark brown solid like, composition: C (62.97\%) H (9.56\%) N (3.50\%) $\mathrm{O}(23.97 \%)$ molecular formula $\mathrm{C}_{42} \mathrm{H}_{76} \mathrm{~N}_{2} \mathrm{O}_{12}$, ESI-MS (m/z) 801.05904.

${ }^{1} \mathrm{H}$ NMR (DMSO-d, $300 \mathrm{MHZ}$ ), 3.3-3.8 ppm (m, 2H-glucose), 4.43 $(\mathrm{m}, 2 \mathrm{H}), 4.52(\mathrm{~m}, 1 \mathrm{H}), 7.10-7.90\left(\mathrm{~m}, 4 \mathrm{H}--\mathrm{NH}_{2}\right), 1.96(\mathrm{t}, 4 \mathrm{H}), 1.33(\mathrm{t}, 2 \mathrm{H})$,

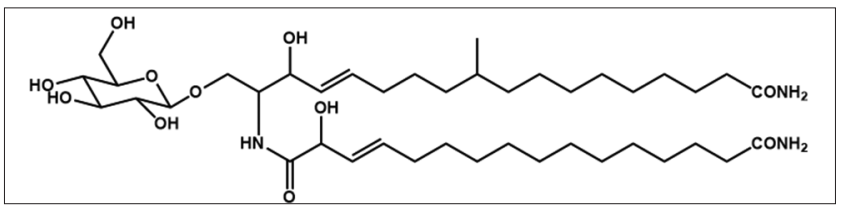

Fig. 4: (E)-N1-((E)-18-amino-3-hydroxy-9-methyl-18-oxo-1-(c(2R, 3R, 4S, 5S, 6R)-3, 4, 5- trihydroxy-6-(hydroxymethyl) tetrahydro2H-pyran-2-yl) oxy) octadec-4-en-2-yl)-2- hydroxyhexadec-3enediamide

$1.29(\mathrm{~m}, 10 \mathrm{H}), 1.25(\mathrm{~m}, 12 \mathrm{H}), 5.62-5.7(\mathrm{~m}, 4 \mathrm{H}), 4.85(\mathrm{~s}, 1 \mathrm{H}), 0.96(\mathrm{~d}$, $3 \mathrm{H}), 2.30$ (t, 2H), ${ }^{13} \mathrm{C}$ NMR (75 MHZ) DMSO-d ; 172-174 ppm (-C=0), $163 \mathrm{ppm}$ (amid group), $110 \mathrm{ppm}(\mathrm{C}=\mathrm{C}), 27-38 \mathrm{ppm}(\mathrm{C}-\mathrm{C}), 73 \mathrm{ppm}$ (C-OH), 75 ppm (C-O-C), 134-135 ppm (C=C). IR (KBr) vmax $\left(\mathrm{cm}^{-1}\right)$ $1700,1650,1725,3400,1650,3100,1000$, and 1062. The results are near about similar to (Fig. 6) [18].

E. coli, S. pneumonia, B. subtilis, S. hyicus, B. sphaericus, S. aureus, and pseudomonas aeruginosa, C. albicans, P. exigua, S. rolfsii, Sclerotinia, scleratiourm Fusarium sp. and Penicillin sp. 


\section{Compound 5}

Dark brown solid like, composition: C (68.61\%) H (11.52\%) 0 (19.87\%) molecular formula $\mathrm{C}_{23} \mathrm{H}_{46} \mathrm{O}_{5}$, ESI-MS (m/z402.60834 ${ }^{1} \mathrm{H}$ NMR (DMSO-d, 300 MHZ), 0.85 (t, 3H), 1.23-1.50 ppm (m, 2H), 2.35 (t, 2H), $3.12(\mathrm{~m}, 2 \mathrm{H}), 1.64(\mathrm{~m}, 1 \mathrm{H}), 1.68(\mathrm{~m}, 2 \mathrm{H}), 3.90(\mathrm{~m}, 1 \mathrm{H}), 3.5(\mathrm{~s}, 3 \mathrm{H}),{ }^{13} \mathrm{C}$ NMR (75 MHZ) DMSO-d6; 172-174 ppm ( $-\mathrm{C}=0), 163 \mathrm{ppm}$ (amid group), $110 \mathrm{ppm}(\mathrm{C}=\mathrm{C}), 27-38 \mathrm{ppm}(\mathrm{C}-\mathrm{C}), 73 \mathrm{ppm}(\mathrm{C}-\mathrm{OH}), 75 \mathrm{ppm}(\mathrm{C}-\mathrm{O}-\mathrm{C}), 134-$ $135 \mathrm{ppm}(\mathrm{C}=\mathrm{C})$. IR $(\mathrm{KBr}) v \operatorname{max~cm}{ }^{-1} 3400,1650$, and 3100. The results are near about similar to [18]

Compound 5 was observed active against:

E. coli, S. pneumonia, B. subtilis, S. hyicus, B. sphaericus, S. aureus, and pseudomonas aeruginosa, C. albicans, S. rolfsii, Sclerotinia, scleratiourm, and Penicillin sp. (Fig. 7).

\section{Compound 6}

Dark brown solid like, molecular formula; C41H78N2010, composition: C (64.87\%) H (10.36\%) N (3.69\%) O (21.08\%), ESI-MS (m/z) 759.06542.

${ }^{1} \mathrm{H}$ NMR (DMSO-d, $300 \mathrm{MHZ}$ ), 3.71 (m, 2H), 3.99 (m, 1H), 1.25-1.29 $(\mathrm{m}, 38 \mathrm{H}), 1.31(\mathrm{~m}, 1 \mathrm{H}),(\mathrm{m}, 2 \mathrm{H}), 1.44(\mathrm{~m}, 2 \mathrm{H}), 2.34(\mathrm{~m}, 2 \mathrm{H}), 1.53(\mathrm{~m}$, $2 \mathrm{H}), 1.96(\mathrm{~m}, 2 \mathrm{H}), 5.67-5.69(\mathrm{~s}, 2 \mathrm{H}), 4.85(\mathrm{~s}, 1 \mathrm{H}), 3.83(\mathrm{~m}, 1 \mathrm{H}), 3.40-$ $5.03\left(\mathrm{~m}, \mathrm{H}\right.$-glucose), $0.88(\mathrm{~m}, 3 \mathrm{H}), 6.8-7.1\left(\mathrm{~s}, 2 \mathrm{H}-\mathrm{NH}_{2}\right),{ }^{13} \mathrm{C}$ NMR $(75$ MHZ) DMSO-d6; 172-174 ppm (-C=0), 163 ppm (amid group), $110 \mathrm{ppm}$ $(\mathrm{C}=\mathrm{C}), 27-38 \mathrm{ppm}(\mathrm{C}-\mathrm{C}), 73 \mathrm{ppm}(\mathrm{C}-\mathrm{OH}), 75 \mathrm{ppm}(\mathrm{C}-\mathrm{O}-\mathrm{C}), 134-135 \mathrm{ppm}$ (C=C). IR (KBr) vmax cm ${ }^{-1}-1600,3400,1650,3100,1000$, and 1062. The results are near about similar to [19].

Compound 6 was found active against:

X. oryzae, E. coli, S. pneumonia, B. subtilis, S. hyicus, B. sphaericus, S. aureus, and P. aeruginosa, C. albicans, $S$. rolfsii, S. scleratiourum, and P. exigua (Fig. 8).

Compound 7

Dark brown solid like, composition: C (57.34\%) H (9.43\%) N (2.67\%) $\mathrm{O}(30.55 \%)$ molecular formula $\mathrm{C}_{24} \mathrm{H}_{49} \mathrm{NO}_{10}$, ESI-MS (m/z) $523.65726^{1} \mathrm{H}$ NMR (DMSO-d, 300 MHZ), $3.37(\mathrm{~m}, 3 \mathrm{H}), 1.25-1.44(\mathrm{~m}, 20 \mathrm{H}), 3.21(\mathrm{~m}$, $3 \mathrm{H}), 1.66(\mathrm{~m}, 2 \mathrm{H}) ., 4.89(\mathrm{~m}, 1 \mathrm{H}), 2.27(\mathrm{~d}, 2 \mathrm{H}), 3.58(\mathrm{~m}, 3 \mathrm{H}), 3.40-5-03$ (m, H-glucose),7.8-7.1 (s, 2H - $\mathrm{NH}_{2}$ ); ${ }^{13} \mathrm{CNMR}$ (75 MHZ) DMSO; 172$174 \mathrm{ppm}(-\mathrm{C}=0), 163 \mathrm{ppm}$ (amid group), $110 \mathrm{ppm}(\mathrm{C}=\mathrm{C}), 27-38 \mathrm{ppm}$ (C-C), 73 ppm (C-OH), 75 ppm (C-O-C), 134-135 ppm (C=C). IR (KBr) vmax $\mathrm{cm}^{-1} 3200,1600,3400,1650,3100,1000$, and 1062. The results are near about similar to [17]

Compound 7 was found active against:

E. coli, S. pneumonia, B. subtilis, S. hyicus, B. sphaericus, S. aureus, $P$. aeruginosa and Xanthomonas oryzae, C. albicans, S. rolfsii, S. scleratiourum, and Penicillin sp., P. exigua (Fig. 9).

\section{Compound 8}

Dark brown solid like, composition: C (55.05\%) H (9.43\%) N (8.02\%) 0 (27.50\%) molecular formula $\mathrm{C}_{24} \mathrm{H}_{49} \mathrm{~N}_{3} \mathrm{O}_{9}$, ESI-MS (m/z) 523.66056.

${ }^{1} \mathrm{H}$ NMR (DMSO-d, $\left.300 \mathrm{MHZ}\right), 3.71(\mathrm{~m}, 2 \mathrm{H}), 1.25-145 \mathrm{ppm}(\mathrm{m}, 16 \mathrm{H})$, $1.51(\mathrm{t}, 4 \mathrm{H}), 3.4 \mathrm{~m}(\mathrm{~m}, 31 \mathrm{H}), 2.61(\mathrm{~m}, 1 \mathrm{H}), 3.0(\mathrm{~m}, 1 \mathrm{H}), 7.16(\mathrm{~s}, 2 \mathrm{H}), 5.11$ $(\mathrm{t}, 4 \mathrm{H}), 5.75-3.40\left(\mathrm{~m}, 1 \mathrm{H}\right.$ glucose). ${ }^{13} \mathrm{C}$ NMR (75 MHZ) DMSO-d6; 172$174 \mathrm{ppm}(-\mathrm{C}=0), 163 \mathrm{ppm}$ (amid group), $110 \mathrm{ppm}(\mathrm{C}=\mathrm{C}), 27-38 \mathrm{ppm}$ (C-C), 73 ppm (C-OH), 75 ppm (C-O-C), 134-135 ppm (C=C). IR (KBr) $v \max \left(\mathrm{cm}^{-1}\right), 3400,1650,3100,1000$, and 1062. The results are near about similar to [17].

Compound 8 was found active against:

X. oryzae, E. coli, S. pneumonia, B. subtilis, S. hyicus, B. sphaericus, $S$. aureus, and P. aeruginosa, C. albicans, S. rolfsii, Sclerotinia, P. exigua, Scleratiourm, and Fusarium sp. (Fig. 10).

Natural antimicrobial compounds generally alter cell permeability as a result causing huge loss of micromolecules and macromolecules from cell

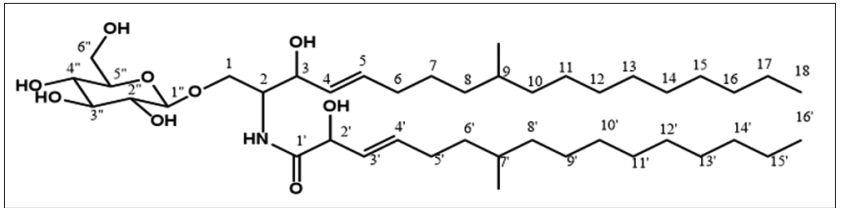

Fig. 5: (E)-N1-((E)-18-amino-3-hydroxy-9-methyl-18-oxo-1-

( ((2R, 3R, 4S, 5S, 6R)-3, 4, 5- trihydroxy-6- (hydroxymethyl) tetrahydro-2H-pyran-2-yl) oxy) octadec-4-en-2-yl)-2- hydroxy-7methylhexadec-3-enediamide

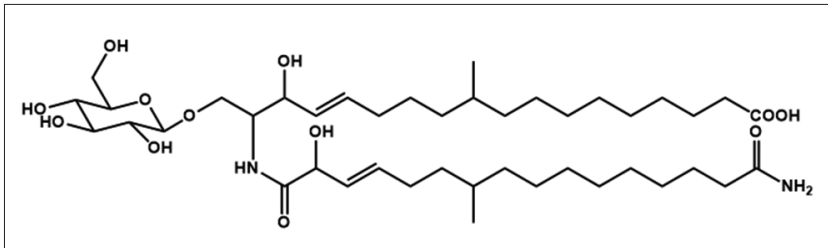

Fig. 6: (E)-17-((E)-16-amino-2-hydroxy-7-methyl-16-oxohexadec3-enamido)-16-hydroxy-10- methyl-18- (2R, 3R, 4S, 5S, 6R)-3, 4 5-trihydroxy-6-(hydroxymethyl) tetrahydro-2H-pyran- 2-yl) oxy) octadec-14- enoic acid

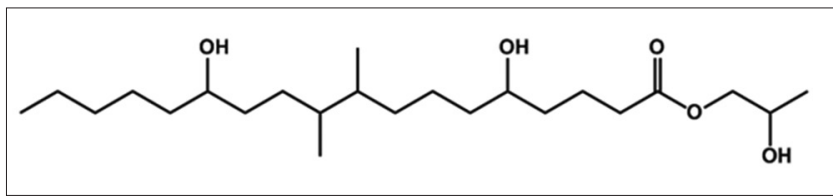

Fig. 7: Hydroxypropyl 5, 13-dihydroxy-9, 10-dimethyloctadecanoate

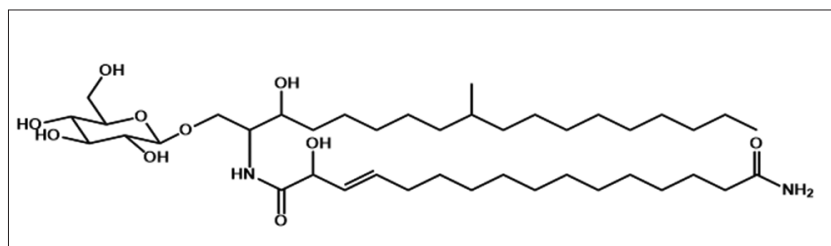

Fig. 8: (E)-2-hydroxy-N1-(3-hydroxy-9-methyl-1-(( $2 R, 3 R, 4 S$, 5S, 6R)-3, 4, 5-trihydroxy- 6(hydroxymethyl) tetrahydro -2H-pyran2-yl) oxy) octadecan-2-yl) hexadec-3-enediamide

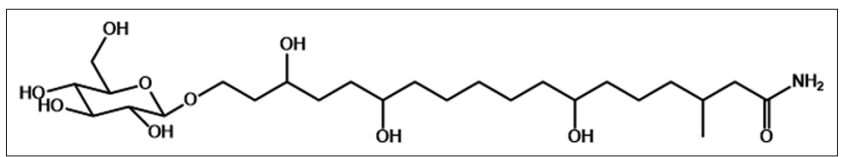

Fig. 9: 13, 16-trihydroxy-3-methyl-18-(((2R, 3R, 4S, 5S, 6R)-3, 4, 5-trihydroxy-6 (hydroxymethyl) tetrahydro-2H-pyran-2-yl) oxy) octadecanamide

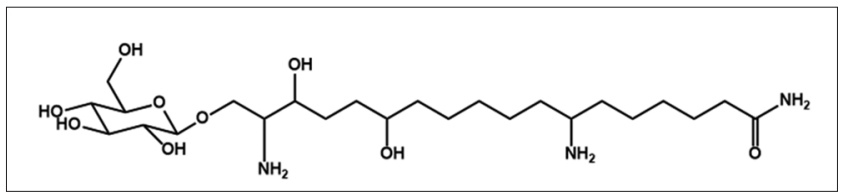

Fig. 10: 17-diamino-13, 16-dihydroxy-18-(( $2 R, 3 R, 4 S, 5 S, 6 R)-3$ 4, 5-trihydroxy-6 (hydroxymethyl) tetrahydro-2H-pyran-2-yl) oxy) octadecanamide

interior, this could be one basis of antimicrobial activity of antimicrobial metabolites. Another worker has reported that antimicrobial metabolite is targeted to lysosome through entry of bacterial cell wall and with 
the bursting of lysosome, antimicrobial compounds target various component of cell cytoplasm interfering their functioning, changing osmolarity of cell resulting in cell lysis $[20,21]$. Another explanation might be that antimicrobial metabolite interferes with membrane function and interact with membrane protein causing deformation in structure and functionality [20]. Some antimicrobial compounds interact directly with microbial cell membrane making pores in the membrane by interacting with phospholipids of membrane. This action rapidly disrupts membrane at several position and result in leaching out of vital cell components [22] Finally, we summarize that structures' of the afforded compounds were confirmed on the bases of different spectroscopic means (NMR and MS) and comparison, and identified as 2-hydroxypropyl 5, 11-dihydroxy-8-(4-hydroxy-5-(hydroxyl methyl) tetrahydrofuran-2-yl) 17-methyleoctadecanate. Finally, compounds 2, 3 , and 4 belong to group of lipid called cerebrosides. Their chemical structure shows maximum similarity with this group of an organic compound. Cerebrosides are a kind of important bioactive substances isolated mainly from sea cucumber [23]. Cerebrosides are known of their antifungal activities at low concentrations [24,25]. Compound 5 is a long chain unsaturated fatty acid which when isolated was in the form of brown oil-like liquid has also isolated some similar natural products from marine bacterial species Compound 6 was also isolated from Aspergillus lentulus, Penicillium thymicola, and Penicillium corylophilum.

\section{CONCLUSIONS}

In this study, a total 10 endophytic fungi were isolated from the C. procera, show a great antibacterial activity against 24 human pathogenic bacteria. All the compounds isolated from crude metabolite showed broad spectrum antibacterial activity against Gram-positive and Gram-negative bacteria and plant pathogenic bacteria. Further growing those on a large scale, modifying culture conditions and supplying some stimulants might help in getting better production of particular bioactive compound which may be a potential lead biomolecule for the synthesis of new emerging antimicrobial agents in the pharmaceutical industry.

\section{ACKNOWLEDGMENT}

The authors acknowledged the facility provided from the School of Biochemical Engineering IIT-BHU Varanasi, for carrying out research work.

\section{REFERENCES}

1. Petrini O. Fungal endophytes of tree leave. In: Andrews JA, Hirano SS, editors. Microbial Ecology of Leaves. Vol. 9. New York: Springer; 1991. p. 179-97.

2. Verma SK, Kumar A, Ashish V, Das MD. Antimicrobial activity of endophytic fungal isolate in Argemone maxicana, a traditional Indian medicinal plant. Int J Innov Res Sci Eng Technol 2014;3(3):10151-62.

3. Luiz HR, Sonia CN, Rita Q, Moraes M, Xiaoning W, Natascha TM, et al. Wedge Coniochaeta ligniaria antifungal activity of the crypticendophytic fungus associated with autotrophic tissue cultures of the Medicin plan Smallanthus sonchifolius (Asteraceae). Symbiosis 2013;60:231-8.
4. Kumaresan V, Suryanarayanan TS. Occurrence and distribution of endophytic fungi in a Mangrove community. Mycol Res 2001;105:1388-91.

5. Teng Y, Yan C, Xing X, Chuan CD. Plant symbionts, keys to the phytosphere. Symbiosis 2013;59:1-14.

6. Silva MG, Furtado NA, Pupo MT, Fonseca MJ, Said S, Silva FA. Antibacterial activity from Penicillium corylophilum Dierckx. Microbiol Res 2004; 159:317-22.

7. Carroll G. Fungal endophytes in stems and leaves: From latent pathogen to mutualistic symbionts. Ecology 1988;69:2-9.

8. Gao F, Dai C, Liu X. Mechanisms of fungal endophytes in plant protection against Pathogens. Afr J Microbiol Res 2010;4(13):1346-51.

9. Schulz B, Wanke U, Draeger S, Aust HJ. Endophytes from herbaceous plants and shrubs: Effectiveness of surface sterilization methods. Mycol Res 1993;97:1447-50.

10. Amal H, Abdessamad D, Proksch P. An endophytic fungus from Nothapodytes foetida that produces camptothecin. J Nat Prod 2007;70(12):1939-45.

11. Shenxi C, Yang Z, Shubin N, Xingzhong L, Yongsheng C. Chen guanacastane diterpenoids from the plant endophytic fungus. J Nat Prod 2011;74(10):2052-61.

12. Tan RX, Zou WX. Endophytes: A rich source of functional metabolites. Nat Prod Rep 2001;18:448-59.

13. Lal M, Neelam T, Verma SK, Das MD. Studies of bioactive metabolites from endophytic bacterial isolate. Int J Sci Eng Res 2016;7(6):598-606.

14. Abraham G, Virgilio BG, Palma-Nicolás JP, Rivera G. Recent advances in antitubercular natural products. Eur J Med Chem 2012;49:1-23.

15. Stierle A, Strobel GA, Stierle D. Taxol and taxen production by Taxomyces andreanae an endophytic fungus of pacific yew. Science 1993;260:214-6.

16. Nielsen ML, Raahave JG, Justesen T. Anaerobic and aerobic skin bacteria before and after skin-disinfection with chlorhexidine: An experimental study in volunteers. J Clin Pathol 1975;28:793-7.

17. Mohamed S. Structural elucidation and bioactivity studies of secondary metabolites from endophytic Aspergillus niger. Indian J Appl Res 2015;5(9):3-7.

18. Mohamed S, Hamdi N, Amal ZH, Mohsen SA. Bioactive secondary metabolities from endophytic Aspergillus fumigates. Struct Elucidation Bioact Stud 2013;41(10):50-60.

19. Humaira N. Structural elucidation and bioactivity studies of secondary metabolites from endophytic Aspergillus niger. Indian J Appl Res 2015;5(9):3-7.

20. Jing T, Xiangie M, Hao L, Jianglin Z, Ligang Z, Minghua Q, et al. Antimicrobial activity of sphingolipids isolated from the stems of cucumber (Cucumis sativus L.). Molecules 2016;15:9288-97.

21. Cateni F, Zilic J, Zacchigna M. Isolation and structure elucidation of cerebrosides from Euphorbia platyphyllos L. Sci Pharm 2008;76:451-69.

22. Xu J, Wang YM, Feng TY, Zhang B, Sugawara T, Xue CH. Isolation and antifatty liver activity of a novel cerebroside from the sea cucumber Acaudina molpadiodes. Biosc Biotechnol Biochem 2011;75:1466-71.

23. Larsen TO, Frydenvang K, Frisvad JC, Christophersen C. UV-guided isolation of alantrypinone, a novel Penicillium alkaloid. J Nat Prod 1998;61:1154-7.

24. Strobell G, Daisy B. Bioprospecting for microbial endophytes and their natural products. Microbiol Mol Biol Rev 2003;67:491-2.

25. Verma SK, Kumar A, Lal M, Das MD. Antimicrobial activity of extract from endophytic fungus in Calotropis procera roots Res. Environ Life Sci 2016;9(2):212-6. 